\title{
The Goal of College Entrance Examinations and Its Implications for School Music Education: A Bourdieusian Perspective
}

\begin{abstract}
Xiaoyu Xiong
University College London, Gower Street, London WC1E 6BT, UK

postgraduate-admissions@ucl.ac.uk

ABSTRACT

Previous researches have emphasized the importance of the application of Pierre Bourdieu's theories in the field of education. However, research on how Bourdieu's theories- habitus, have influenced secondary school music education in China has not been discussed. This article analyses how the habitus of "taking the national college entrance exam (NCEE) as the ultimate goal" has affected Chinese music education. It draws upon on Burnard's (2015). "Bourdieu and the Sociology of Music Education". London: Routledge. The purpose of this article is to highlight the fact that parents, schools and teachers who focus too much on learning outcomes at the expense of the learning process should not be applied to music education, as students may lose their motivation to learn music in such a result-oriented habitus.
\end{abstract}

Keywords: music education, music learning, habitus, Chinese secondary school, NCEE, Chinese music education

\section{INTRODUCTION}

Over the past three decades, the modernisation and globalisation of Chinese society and the transition to a market economy have created new demands and challenges for music education in schools. Due to the disparate political, economic, and social systems existing in China and in Western countries, music education has taken on greater importance. This study attempts to apply Bourdieu's theory to Chinese music education to help understand some of the problems and issues in the field. This study draws on a central mechanism of Bourdieu's theories of practice, habitus. To fully understand habitus, analyses of capital and field will be undertaken to synergistically investigate the psychology, behavioural patterns, and formative impacts of music learning among Chinese secondary school students in the school environment. Scholars note that while habitus is often conceived through family socialisation and childhood development it is continually shaped by outside factors and individual experiences (Di Maggio, 1979). Schooling, in particular, often provides a general disposition, a turn towards what Bourdieu terms "a cultured habitus" (Bourdieu, 1967, p. 34).

Previous research offers a descriptive account of Pierre Bourdieu's mechanism in relation to music education. However, research on how Bourdieu's theory affects Chinese secondary schools is still scarce and has not been paid the attention it deserves. The first part of this essay analyses how Bourdieu's doctrine can be adapted and matched to music education in Chinese secondary schools. The second part is a reflection on how the habitus of "taking the national college entrance exam (NCEE) as the ultimate goal" has affected Chinese music education. The final section considers the further implications of Bourdieu's doctrine for educational practice and policy.

\section{CAPITAL AND FIELD}

Habitus is not an isolated concept and therefore should be considered in relation to social fields and capital. Capital, and cultural capital in particular, is at the core of Bourdieu's view. Cultural capital consists of three forms: objectified, institutionalised, and embodied. The objectified form is the consumption of commodities; the institutionalised form includes the legitimacy that social institutions such as education give to the formation of cultural capital; the embodied form is habitual, i.e. lived (Bourdieu, 1986). Taking this holistic perspective, the habitus of "taking the NCEE as the ultimate goal", the broader concept of habitus, cultural capital, and the educational field should be examined as a whole. The 
habitus of "taking the NCEE as the ultimate goal" is formed in the educational field and under the influence of cultural capital.

The educational field is a network of objective relationships between administrators, educators, educated people, and other participants in education. The field is based on the production, transmission, dissemination, and consumption of knowledge and aimed at the cultivation and advancement of human beings. Within this network, the teacher interacts with the pupils by imparting the cultural capital of knowledge, and the pupils interact with the teacher and other educators by acquiring said knowledge (Shengquan, 2006). In other words, while students can be relatively autonomous in the school they are educated in before they enter it. However, once the student has entered the school field, students are forced to passively accept the cultural values set by teachers and school administrators. Based on my experience of education, students in the school field in China are largely deprived of their autonomy in terms of what they learn and how they behave. At the same time, very few students in China are able to choose the cultural background of their teachers, or choose courses according to their own preferences, because everything is set up in the educational field and all students have to do is to adapt to it, not change it. Education is only concerned with the ends of the educational process. The specific educational process is determined by the instincts, impulses, and interests of the pupils, whereas the ends consist of the socially and politically determined goals of education, and the ends demanded by parents and teachers. It is precisely these ends that dominate the educational field. These extra-educational purposes dominate the relations governing the construction of discourse in the educational field (Yiming, 2013).

This essay argues that the field of schooling has a direct and significant impact on students, teachers, and the formation of habitus. Subjects clash and compete with each other in order to occupy more cultural capital, more cultural power, a higher place in the field. Moreover, students compete with each other for cultural capital such as ranking, honours, and certificates in order to gain higher social and economic status in the society. Teachers, non-teachers, and administrators also engage in this competitive behaviour - the quality and quantity of reproduction determine opportunities for the development of cultural capital and social stratification (e.g. titles, job promotions) in their own field. Differences between teachers and students in terms of possession of cultural capital lead to conflicts, whereby students seeking subjective rights are often subject to the control that comes with the teacher's legitimised status (Mingxing, 2016).

It could be argued that in the current Chinese education system, education has been stripped of its function of serving life; access to further education has become its main driving force due to the existence of the Chinese National College Entrance Examination (NCEE). Teachers, especially those in conventional schooling, take on the responsibility of transmitting the ideology of the dominant society, focusing on the transfer of scientific knowledge. The demands and limitations on education and the 'culture of power' that controls it stem from the dominant culture's domestic social system. Despite an emergent interest in the values the Chinese education system promotes, little attention has been given to the relationship between sociopolitical power and music education (Bai, 1998; Wong, 2001; Zhang \& Harwood, 2002).

\section{HABITUS}

Habitus is defined as a set of behaviours, dispositions, and responses that are formed in early childhood and shape an individual's interaction with the social world. Bordieu outlines the qualities of habitus as durable, transposable, and existing as "structures". These definitions render habitus as long-lasting, applicable to a variety of fields and experiences, and structured by the social conditions that developed it (Bourdieu \& Johnson, 1993).

Habitus can be a way of being or a periodic state which depicts an individual's inclination to act in specific ways and to have certain propensities of conduct, viewpoint, and taste. It incorporates angles of a person's life such as one's individual fashion and inclinations towards particular music and books. It also includes substantial characteristic developments, quirks, and motions. Although it is a personal structure in the sense that it is comprised of the miens of a specific individual, habitus is additionally an inalienably social structure that is powerfully related to other miens within the field of social relations. Each individual's introduction to the social world is conditioned by the introductions of others. In this sense, habitus translates person circumstances and activities in connection to the inclinations and conventions of the group (Olson, 1995). In other words, practice is the item of the relationship between an individual's miens (habitus) and his/her position in a field (characterised in terms of the sum of capital held inside that field) inside the current state of that field. This illustrates the crucial interdependency of Bourdieu's three key concepts: habitus, capital, and field. One's activities are in this manner not the result of one's habitus but of the connections between one's habitus and one's current circumstances - the two act reflexively with each other. The field structures the habitus while the habitus is simultaneously "the basic for agents' understanding of their lives, including the field" (Maton, 2012). Burnard et al. (2015) prove that habitus makes a difference in choosing how to act in response to our activities and the world around us. Thus, habitus is continually evolving. 
The habitus of students consists mainly of relatively fixed psychological states and behavioural patterns that have developed over time, including social adaptation, personality types, career planning, classroom behaviour, the ways and frequency of communication with the teacher outside the classroom, and extra-curricular practices. The psychological states developed in the classroom are self-stable and all the means and conditions necessary to maintain this stability are present (Bourdieu, 1998).

Positioning the Chinese National College Entrance Examination (NCEE) as the most pivotal part of the Chinese education system has inevitably created a "habitus" of learning and teaching for students, teachers, and schools that places the college entrance exam as its central purpose. The NCEE not only shapes teaching practice but also determines the modelling and development of secondary education in China. The relationship between social status and a high standard of education means that parents often place high expectations on their children as individual failure is associated with shame on a familial-national level (Davey \& Higgins, 2007). Many parents prepare their children for the competition from the time they enter kindergarten. Over the next fifteen years, they sacrifice everything they can to help their children to have high grades on the NCEE, taking away their children's childhoods without their consent. The NCEE becomes so important that it overshadows other aspects of a person's life (Wang, 2020). The situation is even worse for most Chinese secondary school students. When Chinese students enter secondary school, all of their studies and life starts to revolve around the NCEE. Therefore, under China's rigorous university entrance exam system, Chinese students have developed a habitus of "taking the university entrance exam for the ultimate goal" in their approach to music study.

According to Mengran Wang (2015), China has experienced a long period of exam-oriented education, with music lessons often being crowded out by subjects related to further studies. Government and school leaders believe that enrolment rates reflect the quality of teaching. The government and schools are still adamant in their opposition to the improvement of music instruction and do not truly comprehend the significance of music instruction for students' learning and development. Therefore, in such an environment, a propensity has developed whereby music education is not afforded sufficient consideration and this attitude has inevitably caused numerous problems. In contrast, the UK National Curriculum, where students take music as a compulsory subject, can be dropped at courses such as KS4. Although other subjects in the UK curriculum are given equally higher importance, such as English and Maths, students still have the opportunity and right to study music in school. However, it seems that Chinese secondary school students do not have the autonomy and right to choose whether or not to take music lessons. Within the school field, teachers and school leaders have absolute command and control over the distribution of the curriculum.

\section{IMPLICATIONS OF EDUCATIONAL PRACTICE}

The habitus of "taking the NCEE as the ultimate goal" directly or indirectly leads to the situation that most school music teachers do not have sufficient class time for music activities and music education. In China, it is my experience that once students enter high school, and particularly in their sophomore and junior years, music classes become the "least worthwhile subject" in comparison to the college entrance exams. Music lessons are overshadowed by science and math, and many music teachers do not have the courage to complain. Moreover, most Chinese teachers still hold the view that music classes are not important and believe that high school students should only use music classes to regulate their nervousness and adjust their bodies and minds to be better prepared to face the NCEE. Everything revolves around the college entrance exams. According to Yu Xingping (2007), in a sample of 143 domestic students in the classes taught by the author, forty-six people (32\%) had no music lessons at all during high school, and 67 people $(47 \%)$ had music lessons but were often preoccupied with their other main courses. The above data shows that nearly $80 \%$ of students do not receive adequate music education in secondary school, especially in high school. The evidence presented thus far supports the idea that the absence of students' engagement in music activities and musical learning has directly contributed to the generally low musical performance of Chinese students. The results of Wang Zhihong's questionnaire survey of ten universities in the Hebei province in 2019 further demonstrates this point. The survey returned 740 valid questionnaires and from those only 193 people had the ability to read music (26\%). Participants without the ability to read music accounted for $74 \%$ of the study.

In light of these statistics, it is necessary to refer to the relevant concepts concerning fields and habitus proposed by Bourdieu in relation to the Chinese context. It is inevitable that teachers in the space of the school field clash and compete with each other in order to occupy more cultural capital, more cultural power, and achieve a higher place in the field. In other words, under the influence of the Chinese NCEE system, teachers of the subjects taught in the NCEE subjects are then given more privileges in the school field, while teachers of music and art-based subjects are necessarily at a disadvantage. In the years that have passed, teachers of all subjects have become accustomed to this habitus of 'teaching privilege', and music teachers have been left in a vulnerable position. 
The habitus of "taking the NCEE as the ultimate goal" has led schools, teachers, and parents to overly focus on learning outcomes and neglect the most significant aspect of musical education - the process. Both parents and schools are more concerned with the outcome of a student's musical 'grade', which leads the student away from pursuing music itself. The best example of this phenomenon is the Chinese music grading test. The music grading test is a comprehensive assessment by experts of a student's musical learning process and achievements, a regular test of how their usual studies and training have gone. However, in China, the results of music grading tests and music competitions can give students a certain degree of advantage in further education by allowing them extra points and priorities to enter prestigious schools as a student with a music speciality. Therefore, many Chinese parents and music training institutions use a grading test as the criterion to assess the level of music education. Many parents believe that if their children pass the examinations at an advanced level, they are equipped with corresponding musical professionalism. Under the dictates of this habitus, music teachers often indulge students in mechanical exercises in order to obtain level certificates and awards, with the consequent loss of systematic and comprehensive musical learning. As such, music education does not pay attention to teaching and consolidating students' basic musical knowledge, instead the emphasis is placed on the idea that "practice makes perfect". Students only play one or a few fixed pieces of music and the boring repetition of exercises strips away the student's joy and enjoyment, resulting in a loss of initiative and motivation for learning.

\section{THE EDUCATIONAL POLICY AND PRACTICE}

I oppose the simple assessment of learning outcomes (objectives, summative assessment), but to focus more on the process of learning. In light of these reflections, I propose the following changes in education policy and practice in order to reduce the negative impact of examcentric habitus on Chinese music education. The following issues need to be considered in the future development of music education, including national policy support, development or reformulation of music curriculum standards, strengthening the training of music teachers, and improving the remuneration of music teachers.

1. National policy support: Chinese administrators should reposition the music curriculum in school education. Based on a reflection of the value and role of the music curriculum, the state should reverse its past practice of putting the music curriculum on the back burner. It should enact educational legislation to make music part of the basic national curriculum, on par with subjects such as mathematics, English, geography, and chemistry. It should also be stipulated that in each school, no less than one music lesson per week is allowed.

2. Development or reformulation of music curriculum standards: According to the recently promulgated "General High School Music Curriculum Standards in China" in 2017, the objective of the state curriculum is "through teaching and various lively music practice activities to calculate students' interest, develop the ability to appreciate, express and create music, improve musical literacy, enrich emotional experience and cultivate noble sentiments." Such vague and unfocused teaching objectives do not systematically require students to acquire any musical knowledge or theory, which has also contributed to the low level of musical literacy in China today. Therefore, the development and reformulation of standards for music classes are necessary. The music curriculum's objectives and standards need to detail and specify the musical knowledge and musical techniques that students of each age-phase need to master, for example singing skills, playing musical instruments, performing, and the mastery of rhythm and beat. The situation in China is particular and unique, as there is an urgent need for China to improve the musical accomplishment of the entire Chinese population and to enhance the development of other human abilities through the development of musical competence.

3. Strengthening the training of music teachers and improving the remuneration of music teachers: Currently, there is a long-standing scarcity of resources for secondary school music education in China, with an average of only one or two music teachers per school nationwide. Due to the insufficient importance attached to music education in secondary schools and the poor remuneration of secondary school music teachers, many graduates with high professional qualifications prefer to change careers rather than apply to become secondary school music teachers. This has led to a case where many current secondary school music teachers are not qualified in terms of competence and teaching level. The majority of music teachers are only able to teach students basic music knowledge, and music teachers are not equipped to meet the diverse needs of students for music due to the limitations of their own musicianship. The shortage of music teachers in China has created a vicious circle, which has led to a stagnation in secondary school music teaching. Therefore, I suggest that the government should strengthen the training of highly qualified music teachers and increase their remuneration in order to stop this vicious circle at the root.

\section{CONCLUSION}

Parents, teachers, and schools discourage and avoid allowing students to engage in certain behaviours that do not fit into the goals of the NCEE or do not provide a direct advantage to the child's NCEE achievements. This 
is something that Chinese educators need to ponder: what is the purpose of music education? Apparently, Chinese educators are simultaneously thinking about how to improve the musical abilities of the Chinese people. According to a recent report (the General Plan for Deepening Education Evaluation Reform in a New Era, 2020), the Chinese government has issued a notice to include the study of art subjects such as music, art, and calligraphy for primary and secondary school students. It further encourages their participation in practical art activities organised by schools, increases artistic academic requirements, and is preparing to include art subjects in the pilot reform of the secondary school examination. These developments mean that music will be studied quantitatively and included in the examination system, and students will be required to take a written music examination. However, I am opposed to this policy. Why must music education be delivered in the form of examinations, especially if you want to improve a certain aspect of students' abilities? Inappropriate education often annihilates valuable differences between people. Music education should not be aimed at examinations and competitions, and competition-type assessment mechanisms should not apply to music education. While examinations are a valid way of testing learning outcomes, standardised answers can assimilate children and rob them of the courage to be creative and respectful of differences. Such standards are inappropriate for music education and examinations are even less likely to achieve the desired aims for and effects of teaching musical ability.

\section{REFERENCES}

[1] Bourdieu, P. (1993). The Field of Cultural Production: Essays on Art and Literature, edited and introduced by R. Johnson. Cambridge: Polity Press.

[2] Bourdieu, P. and Passeron, J. (1990). Reproduction in Education, Society and Culture. Cambridge: Sage.

[3] Bourdieu, P. (1977). Outline of a Theory of Practice. New York: Cambridge University Press.

[4] Burnard, P., Hofvander Trulsson, Y., and Söderman, J., eds. (2015). Bourdieu and the Sociology of Music Education. London: Routledge.

[5] Davey, G., De Lian, C., and Higgins, L. (2007). The University Entrance Examination System in China. Journal of Further and Higher Education, 31(4), pp.385-396.

[6] Georgii-Hemming, E. and Westvall, M. (2010). Music education - A Personal Matter? Examining the Current Discourses of Music Education in Sweden. British Journal of Music Education, 27(1), pp.21-33.
[7] Ho, W. (2011). School Music Education and Socia Change in Mainland China, Hong Kong and Taiwan. Leiden: Brill.

[8] Ho, W., \& Law, W. (2004). Values, Music and Education in China. Music Education Research, 6(2), pp.149-167.

[9] Jiaxing Xie, \& Bo Wah Leung. (2011). Students' motivation to study music: The mainland China context. Research Studies in Music Education, 33(1), 59-72.

[10] Maton, K. (2012). Habitus. In M. Grenfell, ed., Pierre Bourdieu: Key Concepts. Durham: Acumen.

[11] Mingxing, Z. (2016). The Construction of a Deep Learning Field by Fusing MOOC and Flipped Classroom. Modern Distance Education Research,16(1), pp.186-192.

[12] Olson, K. (1995). Habitus and Body Language: Towards a Critical Theory of Symbolic Power. Philosophy \& Social Criticism, 21(2), p.35.

[13] Shengquan, L. (2006). On the Field of Education. Peking University Education Review.

[14] Wang, M. (2015). An Analysis of the Current Situation of Music Education in China. Northern Music, 35(24), p.180.

[15] Wang, Y. (2020). Does a Test-Driven Education System Fulfill General Education Expectations?: A Study on the National College Entrance Exam in China. M.P.P. Thesis. Georgetown University

[16] Wenlan, W. (2005). Music Education Innovation in Foreign Countries and An Analysis of the Current Situation of Music Education in China. Journal of Northwest Normal University (School Science), 42(2), pp.131-132.

[17] Yiming, X. (2013). On Cultural Capital and Discourse Construction in the Educational Field: A Student Perspective. Social Science Hunan, 2013(6), pp.269-27. 